\title{
Evidence-based Nursing in the IED: From Caring to Curing?
}

I Jette Ernst ${ }^{1}$

PhD Fellow, Department of Language and Communication, University of Southern Denmark, Denmark

\begin{abstract}
Danish hospitals are major sites of healthcare reform, and new public management accountability and performance management tools have been applied to improve the quality and efficiency of services. One consequence of this is that nurses' work in hospitals is increasingly standardized through medical evidence. Using Bourdieu's theory of practice in combination with an ethnographic field study, it is analyzed how the nurses of a Danish Integrated Emergency Department respond to the changing conditions of work. It is illuminated how two opposing approaches to nursing of humanistically and pluralistically oriented caring, and evidence-based scientifically oriented curing inform nursing in the department. The curing approach is however trumping the caring approach. Curing creates new nursing career pathways and is by some nurses embraced with enthusiasm. For others, the new situation creates tension and distress. It is illustrated how the nurses position their practice in relation to the changing working conditions taking sides for either curing or caring, or finding a way to maneuver in between the two. The article argues that the normative enforcement of the curing approach may carry unintended side effects to the goals of quality and efficiency enhancements.
\end{abstract}

\section{KEY WORDS}

Caring / curing / healthcare reform / hospital / medical evidence / NPM / nursing / standardization DOI

10.19154/njwls.v6il.4885

\section{Introduction}

he article draws on a broad range of ethnographic data and explores how the nurses of a Danish Integrated Emergency Department (IED) ${ }^{1}$ are affected by and participate in quality and efficiency-leveraging initiatives in the shape of evidence-based standardization of their practice. Inspired by Bourdieu's theory of practice, it is analyzed how the inroads of new rules to practice transform the field of work, and the logics and rationalities that guide these nurses' differing responses to the changes are identified and explained.

There is currently a strong turn toward evidence-based and standardized practice in Danish hospitals (Knudsen et al., 2008). The development is characteristic of an

\footnotetext{
${ }^{1}$ Email: jette-ernst@sdu.dk.
} 
international trend of increasing regulation of hospital services in a quest for quality and efficiency gains (Saltman et al., 1998) where medical evidence and standardization of clinical practice have come to serve as new public management (NPM) reform tools to regulate professional behavior (Nickelsen, 2009). In nursing, the uptake of evidence-based practice has spread with considerable force over the last decade, and many nurses have eagerly adopted this practice form (Boge \& Martinsen, 2006; Delmar, 2005; Holmes et al., 2008; Jenkins, 2014). The turn toward medical evidence in nursing reinforces and accentuates a historical divide within the profession, which addresses the question of what counts as legitimate knowledge to inform practice, and essentially centers on what constitutes the core of nursing (Petersen, 1998; Taylor \& Allen, 2007), or the nursing ethos (Apesoa-Varano, 2007; Fagermoen, 1997). This development is, however, not unproblematic, as medical evidence has increasingly come to rule out other knowledge bases to inform practice (Baumann, 2010; Boge et al., 2009; Holen, 2012), which raises questions about the capacities of the paradigm to designate one best practice (Holen, 2012; Holmes et al., 2008; Nolan \& Bradley, 2008).

The article can usefully be located within a body of work, which has a critical focus on the connection between health care reform, healthcare organizations, work, and professionals. There is a tendency in the literature that the reactions and actions of healthcare practitioners to changing conditions of work are conceptualized in either monolithic terms as, for instance, "a profession under pressure," in binary related pairs either for or against changes, or as a choice between commitment to values of the profession or values of the organization. Furthermore, research in the field tends to be concentrated at either the macro or micro analytical level. For example, Hujala et al. (2014) describe how healthcare professionals get caught between a management logic and a professional logic in the wake of healthcare and NPM reforms. Likewise, Evetts (2011) links NPM to the notion of professionalism and describes how two oppositional idealtypes of organizational and occupational professionalism emerge. Nickelsen (2009) did an intervention study in a Danish hospital going through an accreditation process. He concludes that evidence-based practice divided the nursing staff in two groups, for or against accreditation. Allen and Taylor (2007) describe how nursing is split in a tension between professional and service visions of practice, and Apesoa-Varano (2007) and Mulhall (2002) put forth that nursing is caught in a dilemma between professionalism through academic knowledge and through caring. Healey (2009), Selberg (2013), and Latimer (2014) describe professions under pressure due to changes instantiated by public sector reform and NPM. Finally, Gibson (2013) discusses how NPM puts pressure on nurses to take up an enterprising identity. While this research brings valuable insight into the topic of public sector reform and the work of nurses, the ambition of this article is to contribute to the debate by exploring and refining nurses' responses in practice. Moreover, the article aims, through the connection of micro and macro analytical levels, at establishing an understanding of the dynamics and relationship between daily nursing work and the hospital as organization embedded in a context of wider societal and political forces. The study points to, and questions, an often taken-for-granted presupposition of the medical field that evidence-based practice can be equated with best practice, and that its application in practice is an implementation issue where barriers in the shape of "wrong" mind-sets or faulty cultures must be overcome (e.g., Hauck et al., 2013; Kjerholt \& Toftdahl Sørensen, 2014; Schaffer et al., 2013).

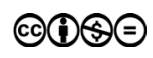


The article proceeds as follows: First, I present the key theoretical concepts of field, habitus, and capital of Bourdieu's theory of practice that guide the present analysis, followed by the analytical and methodological frame for the article. I then proceed to the macro level findings wherein the transformations that paved the way for the turn toward evidence-based and standardized practice in nursing are explained. Subsequently, the transformations are linked to nursing practice in a Danish IED, and it is analyzed how the nurses are affected by the changed working conditions and respond by positioning their practice as caring, curing, or as navigating in between the two. Finally, I discuss the implications of my study for the dominant understandings of how quality and efficiency in nursing work can be achieved.

\section{Field, capital, and nursing practice}

With the theory of practice or "theory of the generation of practices" (Bourdieu, 1977, p. 72; Bourdieu, 1998), Bourdieu wanted to explain how the social order is both sustained and transformed by the same mechanisms. The central concepts of the theory are the interdependent working notions of field, habitus, and capital, which are briefly introduced and explained in this section before they are applied as analytical tools in the forthcoming sections.

Habitus is a capacity and propensity for doing one thing rather than the other, for ways of understanding the world, and being in the world. It accounts for the evaluative and perceptual schemata that agents apply in their everyday life and it works as a propensity-informing practice. It is acquired during childhood and under constant development (Bourdieu, 1990). The concept is hence pivotal in connection with the concepts of profession and vocation (Bourdieu, 1981). Becoming a nurse implies the shaping of a professional habitus through secondary socialization by way of the educational system, the work field, and society as a whole. Through the nurse education, it is learned how to perceive the professional world and to act in it. The habitus is thus what is learned and has been internalized to an extent where one acts with a large degree of automatism. Habitus is also the concept that allows for an explanation of why some staff and not others thrive with instituted changes to work.

The field is the context where practice unfolds. The configuration of it, which we must understand in dynamic terms, is setting the framework for practice (Tatli, 2011). It is what makes some actions possible and worth aspiring for, while at the same time making others not worthwhile or perhaps illegitimate. A good match between habitus and field results in a propensity for appropriate or strategic action ${ }^{2}$ (Bourdieu, 1998) for the practitioner who feels at home with the conditions pertaining to the field and knows how to act in it. This embodied knowing what to do is hence nested in a dialectic of relations between a habitus and the objective conditions, which delimits the space for practice (Wacquant, 2015). In the present study, nursing is analyzed as a subfield of the medical field, which, in turn, is embedded in the healthcare field and the broader social space, that is, a principle like that of Russian dolls.

Bourdieu explains the interdependence of field, habitus, and capital through the metaphor of playing a game ${ }^{3}$. Agents are adjusted to the game, and the more their habitus is in consonance with it the more virtuous their acts, and the better the feel for where the profits of the game can be obtained. Profits are what Bourdieu terms socially 
efficient resources or capital. Accordingly, every field is characterized by its own forms of capital, which is that which has a particular value to its members and act as markers of differentiation. In this way, capital may accrue meaning at the symbolic level (Bourdieu, 1985). In the medical field, scientific knowledge is a prime form of capital (Larsen, 2008). The present study of the IED nurses' responses to the standardization of their practices is theorized as strategies in practice resulting in position-takings that accommodates the past and the present via habitus (Robbins, 2000). Henceforth, I understand strategies as acts that reflect nursing habitus in the meeting with the changing conditions of work.

\section{Methodology}

Studying and explaining nursing practice with a Bourdieuan practice approach is to study the dialectic between the mundane everyday work of the nurses and the structures and genesis of the field which embed the mechanisms that sustain or transform work. Here, theory, methods, and the generated data are related in what we could term an interwoven research patchwork (Yanow, 2012). Therefore, in the two subsections that follow, the research results are presented as macro-level and micro-level findings, which reflect that subjective phenomena are shaped through the limitations and possibilities set by the conditions of the wider field (Bourdieu \& Wacquant, 1992, p. 97).

I draw on a sample of data produced for my PhD dissertation. To inform me of the structures and genesis of the field, and hence the emergence of evidence to inform nursing practice, I make use of policy documents and publications from the Danish Regions, the Ministry of Health, the Danish Health and Medicines authority, and the local Region in which the hospital where I performed my studies is placed. I also include research articles from peer-reviewed journals, anthology chapters, newspaper articles, conference proceedings, articles from the journals of the Danish nursing organization, and the Danish Medical Association as well as posts on the websites of both organizations. Finally, I was given an e-mail account as well as access to the intranet of the hospital where I conducted my fieldwork, which allowed me to read internal documents related to the topic of quality and efficiency enhancements of practice.

The fieldwork took place in an IED employing approximately 108 healthcare professionals of which the large majority was nurses. I undertook 118 hours of participant observations with nurses and doctors, sat in on a broad range of meetings in the department totaling to 26 of varying duration, and I participated in departmental events such as a pizza evening and the annual Christmas meeting. Furthermore, I undertook 17 semi-structured interviews (Kvale \& Brinkmann, 2009) lasting between 45 and 90 minutes with staff and management, and two focus group interviews of each 120 minutes with the participation of five nurses each. The interviews were dictaphone recorded and transcribed, and all data referring to staff have been anonymized.

The participant observations, which include 25 nurses and 9 doctors, constitute the dominant micro-level data. Participants at different levels of experience and with different functions in the department were recruited. I asked specific staff for participation with respect to a criterion that held for the data generation, in general, of getting as many perspectives as possible on themes, hence, adopting the epistemological position that the multiplicity of coexisting and oftentimes competing points of view allow for a

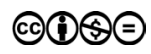


nuanced perspective to inform understandings (Bourdieu, 1989, p. 18; Bourdieu, 1999; Rock, 2001, p. 31).

The observations were carried out in cycles of differing intensity over the year and took place in stretches between 3 and 5 hours on different days of the week including weekends and holidays, at different times of the day, and at night. Daily work activities and breaks were observed. Dressed like the particular staff I followed, I observed both emergency situations and mundane clinical and caring situations. Since I do not hold a clinical education myself, my participation was naturally limited to tasks such as getting food, blankets, clothes, etc. for patients. However, through such participation, I tried to enter the world of clinical practice in the department and embody the experience of the work. Moreover, I sought to grasp the relations in which practices and practitioners were embedded. While having stated the number of observational hours to 118 , the actual number went well beyond because many unplanned encounters with staff took place either before or after the planned observations, for example, in the staff rooms. These conversations are treated as data in line with other data. My observations and experiences were jotted down when possible on a notepad, which I carried in my uniform pocket.

The analysis of fieldwork data began in the field or while reading through various texts, e-mails, etc. Data generation and analysis was as such a continuous process where I went back and forth between theory, the ethnographic material of written sources, fieldnotes, and interview transcripts. I used the process to familiarize myself with the material to bring forth ideas of what it was saying, opening up analytical possibilities (Coffey \& Atkinson, 1996). Themes were constructed from both data and theory; hence, an inductive-deductive combinational approach was applied, which allowed me to discover unforeseen things as well as applying theory to data. Chunks or units of meaning were grouped to form analytic themes (Kunda, 2013) I could work with, and themes were thus constructed from the data with reference to the research question. Through this process, the three ways of positioning nursing practice in relation to the changing conditions of work as caring, curing, or in between the two emerged from the data. The third "in-between" nursing position thus emerged as the irregularity (Coffey \& Atkinson, 1996, p. 47) through data that did not comply with the caring and curing dichotomy and therefore had to be assigned analytic value in themselves.

\section{Macro-level findings: A healthcare field under pressure}

In the following, I elaborate on the concepts of evidence and standardization, and the reason for their successful reception in the healthcare field and within nursing. I seek to place the turn toward medical evidence in its broader historical and political context, thereby cultivating an epistemological awareness that things could have been different (Bourdieu, 1998, p. 40); that the development which now may seem natural results from battles in the field where different positions have fought to make their views on medical "best practice" valid and accepted as the most legitimate.

\section{The neoliberal modernization project}

The turn toward evidence in the hospital sector is nested in the context of forces, developments, and changes in the Danish welfare state. It can be understood as a response to 
perceived problems in healthcare and in the public sector in general (Nickelsen, 2009). Bourdieu $(1989$, p. 21$)$ asserts that the construction of a new order happens through the construction of "a vision of the future," "a creative prediction" designed to impose a certain view on reality. Economist Ove Kaj Pedersen (2011), put forth that the thematization of the Danish welfare state as a problem began with neoliberalist critiques of the public sector voiced nationally and internationally. Large and bureaucratic entities were seen as working in a distant, estranged, and inefficient manner in relation to citizens. Pedersen $(2011$, p. 26) contends that "today neoliberalism is the dominating form of economic and political thought [...] it sets the frame for the economic policy of most western governments, and for the most important international organizations and their counseling." It is thus the pressure from neo-liberalism and globalization that has resulted in ongoing public sector modernization programs (Pedersen, 2011).

In the Danish hospital sector, the main forces driving "modernization" were the publication of reports by powerful and respected agents in the field, such as The Organization for Economic Co-operation and Development (OECD) and The World Health Organization (WHO) that pointed to severe problems related to escalation of health care expenditure and the quality of services (Knudsen et al., 2008). Already in 1984, the WHO had suggested that all members adopt quality assurance mechanisms (Triantafillou, 2014), and in 2000, a devastating health report by the same agent pointed to severe quality problems in Danish healthcare and, in consequence, ranked the Danish system lowest among the EU countries. Later, in 2008, the OECD Economic Survey of Denmark explicated that the healthcare sector was "the essential future challenge for the Danish Society" (Knudsen et al., 2008, p. 19). The 2007 extensive local government reform had as one of its key objectives to win control with the hospital sector. The ensuing centralization of responsibilities and authority can henceforth be interpreted as an attempt at a power balance shift in state favor (Christiansen, 2012), ${ }^{4}$ which is reflected in the introduction of NPM steering tools. They address issues such as accountability, performance management, and consumer choice (Greve, 2006). An objective of the application of NPM is to break with what is seen as self-steering healthcare professions whose powers and monopolies should be curbed to attain the projected goals (Kamp et al., 2013; Kirkpatrick et al., 2011) and to turn hospitals into enterprises (Kirkpatrick et al., 2011). Along these lines, steering, control, and benchmarking have become key activities and tools in Danish hospitals (Christiansen, 2012; Knudsen et al., 2008; Triantafillou, 2007). Another way of attaining a break with traditional conduct in the sector is to encourage entrepreneurial capacities within hospital organizations (Exton, 2010; Triantafillou, 2007), which include inspiring employees to become organizational change agents who function as spearheads for the advancement of initiatives related to quality and efficiency enhancements in their organizations (Evetts, 2009; Gibson, 2013).

In summary, the development in the hospital sector is characterized by attempts at a break with traditional conduct, and a move from a relationship of reliance on highquality services to a perceived need for systematic control and monitoring of practice (Triantafillou, 2007). At the same time, and in congruity with the tradition in Denmark, the health care professions have, through their associations and spokespersons such as nursing researchers, played an agentive role in suggesting innovations to improve practice (Kirkpatrick et al., 2011; Triantafillou, 2014), which resonates well with NPM's incitement to entrepreneurial activities.

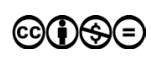




\section{The turn toward evidence-based practice in the medical field}

Improvements in the quality and efficiency of services are thus regarded as key objectives for the hospital sector. Evidence-based medicine offers to meet the demands for accuracy and certainty in clinical decision making (Baumann, 2010) because evidence-based knowledge is seen as universal and, hence, context independent as opposed to personal clinical judgment (Timmermans \& Kolker, 2004). Standardization is the implementation of evidence in practice, and evidence-based and standardized clinical practice is henceforth positioned as a solution to the perceived quality related problems of the sector (Nolan \& Bradley, 2008; Triantafillou, 2014).

The development of evidence-based medicine gathered speed in the $80 \mathrm{~s}$ and $90 \mathrm{~s}$, and the now well-known knowledge hierarchy with randomized clinical trials at the apex was developed. Since then, the promotion of evidence in medicine has evolved into a world-wide movement with a considerable power base (Timmermans \& Kolker, 2004). Although Sackett et al. (1996, p. 72) pointed out that: "Good doctors use both individual clinical expertise and the best available external evidence, and neither alone is enough," evidence-based clinical practice has increasingly evolved to accept only external evidence for the formation of clinical decisions because it has acquired a status of truth and reliability. In consequence, instead of working juxtaposed, external evidence rules out the knowledge held by the individual professional (Holmes et al., 2008; Lester \& O’Reilly, 2015; Nolan \& Bradley, 2008). Evidence-based medicine is thus essentially concerned with designating legitimate knowledge as the basis for best clinical practice, and separating it from other forms of knowledge (Timmermans \& Kolker, 2004), and the healthcare field is henceforth engaged in what Timmermans and Epstein (2010, p. 80) name "a massive standardization movement called evidencebased medicine."

\section{The scientification of nursing}

Having elaborated on the explanations for the progress of medical evidence and standardization in the medical field, I now place nursing in this context by describing two coexisting approaches to nursing through the notions of curing and caring that reflect a long-standing discussion in the field concerning the role of health professionals in relation to their work (Baumann et al., 1998; Webb, 1996). The section also sheds light on the reasons behind the suggested general movement from caring to curing within the profession.

Curing is associated with the medical profession, with science and evidence, with disease cure through sophisticated techniques, if possible, performed without touching patients' bodies (Glouberman \& Mintzberg, 2001a, 2001b). Curing in nursing is evidence-based and rests on the logics of evidence-based medicine. It seeks to upgrade a profession that is historically and stereotypically associated with tacit and unskilled care work by scientizing it and professionalizing it (Apesoa-Varano, 2007; Mulhall, 2002), and it opts for a position next to medicine. The curing ethos understands nursing as measurable activities informed by cumulative research-based knowledge. Caring, on the other hand, is typically associated with traditional nursing, with basic care for patients, with comfort and interpersonal intimacy (Glouberman \& Mintzberg, 2001a, 
2001b). It works within an emphatic terrain that focuses on patient and illness in connection (Apesoa-Varano, 2007, p. 258; Petersen, 1998), and it represents what used to be seen as the core of the discipline, the old nursing ethos (Apesoa-Varano, 2007; Boge \& Martinsen, 2006; Holen, 2012; Latimer, 2014) that cannot be standardized and counted (Boge et al., 2009; Holen, 2012). The ethos of a profession ${ }^{5}$ is understood as the deep unconscious principles that result from learning in a specific environment, which makes some actions natural and others unnatural (Bourdieu, 1977, p. 77). Caring as practice, as ethos, and nursing position claims its differential distinction through that which medicine is not.

Curing and caring are hence informed by two different world-views or paradigms (Apesoa-Varano et al., 2011; Boge \& Martinsen, 2006; Glouberman \& Mintzberg, 2001a; Mulhall, 2002) and some authors suggest that we understand them as end-points on a paradigmatic continuum equally important in patient care (Baumann et al., 1998; Webb, 1996) or see them as inextricably interwoven (Kottow, 2001). Nevertheless, their relation is characterized by the dominance of curing over caring, which reflects the power of the medical profession to control the other healthcare professions (Battilana, 2011; Glouberman \& Mintzberg, 2001b; McMurray, 2011). Nursing as a practice and profession is hence nested in the context of the medical field with its hierarchical power relations where doctors have historically ensured and defended their dominance, and nurses have fought to claim recognition as a profession. The nurses' struggles for recognition and distinction in the medical field, where the scopes and boundaries of professional practices are at stake, are described and analyzed by several authors, for example (Allen, 1997), (Apesoa-Varano, 2007), (Witz, 2003), (Larsen, 2008), (Larsen, 2013). A central focus in the struggles is the perceived difference between the ethos of disciplines. This difference is concerned with the kind of knowledge required in practice, and differences in the scope and type of abilities in practice (Timmermans \& Kolker, 2004). The struggles can hence be understood as symbolic demarcations between professions, developed and negotiated continuously.

Curing in nursing includes processes of classification that demarcates what can count as legitimate knowledge to inform decisions in practice and what counts as good practice. The scientification of the discipline therefore creates difference in practice leading to intra-occupational stratification (Apesoa-Varano, 2007). Dominant positions within nursing have adopted curing as the new legitimate ethos (Birkelund, 2006). In the journal Sygeplejersken (The Nurse) ${ }^{6}$ of the Danish Nurses' Organization, evidencebased practice is profiled in several articles often through the use of persuasive arguments of an invigorated nursing identity, and a nursing praxis founded on "true knowledge" (e.g., Hansen et al., 2012; Korsbek et al., 2008). It is hence characteristic that "evidence-based" is put forth as representing the certain, the true, or the indisputable (Baumann, 2010; Delmar, 2005; Holmes et al., 2008; Nolan \& Bradley, 2008).

To sum up, two approaches to nursing, which we can place at each their end-points on a paradigmatic continuum, can be identified in the literature and the described positioning battle of nursing can be analyzed as a battle for social legitimacy in the medical field. In this battle, knowledge is the symbolic resource at stake. The caring pole has however come under pressure because the political level and dominant positions in the field are promoting quality and efficiency enhancements as standardization and audibility of practice, which facilitates nursing for control, categorization, and measurement (Holen, 2012). 


\section{Micro-level findings: Nursing in the IED between curing and caring}

The IED departments are spearheads in the modernization and restructuring of the Danish hospital sector. They were established to gain control with what is characterized as a "silo" and disintegrated medical specialist organizational system (Knudsen et al., 2008). They work as the central admission units in larger acute care hospitals where specialist services are available 24 hours a day to service patients with emergency care needs.

The emergency concept covers acuity levels on a wide span from non-acute to very acute, and the departments treat a great variety of patients and patient conditions. In the studied department, approximately two-thirds of admitted patients suffer from minor illnesses and injuries that do not require hospitalization and less than $3 \%$ of hospitalized patients suffer from life-threatening conditions.

The changing managements of the department have been dedicated to support and push the steadily increasing focus on quality, safety, and efficiency. The dedication reflects the progressive line the hospital board has decided upon toward the quality issue as well as the air of competition in which the progressive line is enveloped. For example, the hospital board decided that the hospital should opt for participation in the Patient Safe Hospital program as one of only five Danish Hospitals. The program is run by the Danish Society for Patient Safety, founded in 2001, and part of the international Patient Safety Movement, ${ }^{7}$ which is described as a multi-million dollar industry (Travaglia \& Braithwaite, 2009). Nursing practices in the department have been profoundly influenced by this program as well as by the accreditation programs that until the end of 2015 are mandatory for all Danish hospitals.

In the following where the results of my fieldwork appear, it is analyzed how the nurses respond to the changed working conditions by positioning their practice as caring, curing, or as maneuvering in between the two.

\section{Moving ahead: the curing ethos}

Examples of evidence-based procedures applied to nursing practice in the department are the systematic measuring of "the six (parameters) that save lives" ${ }^{\text {, a }}$ vast amount of clinical guidelines, increased electronic documentation in relation to admission, diagnosing, and treatment, and the introduction of a triage system wherein patients are admitted systematically according to need. The department was among the first in Denmark to use this acuity assessment tool. Beth, an experienced nurse, explains ${ }^{9}$ :

\footnotetext{
Triage means that we systematically assess the acuity level of patients based on their symptoms. As a nurse I think that's fantastic! I mean, we've moved from early, and often wrong, diagnosing to looking instead at symptoms, and all patients are admitted in the same way (fieldnotes).
}

From my observations and conversations with staff, I learned that many nurses participate actively in the promotion of evidence-based practice, and have approached the 
curing ethos with enthusiasm. One of them, Amy, expresses how she believes that evidence legitimizes nursing in relation to medicine:

Evidence is the only right thing, and the only thing on which we can base our arguments. I have no respect for nurses who want recognition because they feel that something is this or that way. No wonder doctors don't lend an ear to that (fieldnotes).

Amy's remark points to how curing, for some nurses in the department, functions as a symbolic marker of professional progress. By situating nursing as curing in alliance with medical practice, Amy, for example, creates a relational and distinctive distance to the nurses who adhere to the traditional caring paradigm of nursing.

The process of introducing evidence-based nursing in the department has brought along new positions, and several nurses in the department have been assigned special posts offered in relation to the Patient Safe hospital and accreditation programs. The following two excerpts illustrate the enthusiasm with which curing has been approached. The first comment by Janet is typical for the nurses who hold special functions in the department. The latter nurse, Sue, is somewhat frustrated because she thinks the management is doing too little to push the evidence-based agenda forward:

I like being one of those who introduce new things. I like having a say in how things should develop, and I'm fond of the teaching role implied in my function. In this way, I'm bringing the most recent knowledge into the department so that we can increase our skills continuously, and I'm trying to make my colleagues jump on the bandwagon (fieldnotes).

I don't think the management invests enough resources and will in the project. For instance, people here lack a basic level of knowledge about quality. I think we should arrange some courses because if people understand the reasons for quality related changes; why they are important, and what it's all about, they'll be more motivated to change their work habits (fieldnotes).

The idea of nursing professionalism displayed by the nurses in these excerpts corresponds well to the scientific oriented and entrepreneurial nurse described by more authors (e.g., Apesoa-Varano, 2007; Exton, 2010; Gibson, 2013; Mulhall, 2002). Possessing a habitus that easily adapts to the changes of the work field, the curing ethos makes sense to these nurses. Because the term 'evidence-based' is equated with proof and truth, scientific medical knowledge is capital working as "aces" (Bourdieu, 1990) in the clinical game symbolizing nursing progression and creating distinction in practice for these nurses.

\section{Caring: At the heart of nursing skill}

The caring ethos stands out through its differential relation to the clinical practice of doctors as well as the curing nursing ethos. Fundamentally, the tension between caring and curing rests on the issue of "good nursing," which is related to how nursing is legitimized in the medical field. Nurses adhering to the caring ethos criticize the heavy reliance on standards and systems that has come to dominate nursing in the department:

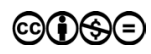


You ask me what we did before we got the triage system. Well, we did what we've always done we relied on experience and our clinical gaze. We were allowed to be nurses back then. Don't misunderstand me because I like to work here, but our professionalism is not respected anymore. We surely detect some errors through this system, we surely do. But we also detected errors earlier, and there are things that fall through the system, and errors that are only identified because we use our clinical gaze and common sense [...]. Sometimes, I know from just looking at a patient that something is entirely wrong even if the physiologic severity variables look fine. I think it's regrettable that this old form of nursing gets lost (Lily, fieldnotes).

The excerpt shows how the concept of the clinical gaze, as a specific competence, is linked to the caring ethos. Possessing this competence of intuition built on experience in combination with the nurse's common sense used to be capital in the field. During my field work, I learned that for these nurses, a discourse on an ideal-type nurse exists, who is central for many nurses' early work experiences and ideas of what nursing is. She is first and foremost characterized by her experience, and her "old school style" of nursing. In the excerpt below, this is termed real nursing work. Zoe and Josephine recalls:

I used to have a superior of that old school type in a former employment. She was awesome because she knew everything, yet at the same time she made room for us to practice our skills (fieldnotes).

We have one social and health care assistant employed here, and when I think about it, she does, what I'll term, real nursing work. I mean, she does the care work, talks to the patients, comforts them, and brings them food and such things. I think that talking to the patients ought to be a core task for us nurses, but we haven't got time for it anymore (fieldnotes).

Some nurses address the competitive situation of the new department in relation to the other departments of the hospital. Being first or being superior in the application of evidence-based practice seems to be a way gaining acknowledgement from the neighboring departments. The management has therefore set the bar high which puts staff under pressure. The following conversation between two nurses exemplifies how the pressure is handled:

Kimberly: Now we must measure the physiologic severity variables three times each 24 hours. Rather than doing this for the benefit of the patients, I believe what really matters is showing the other departments that "we can actually do this."

Selma: Yes, but I don't do that. Not each time. I believe I'm capable of assessing whether it's necessary or not. I mean, I really think we must consult our clinical gaze as well (fieldnotes).

In sum, the excerpts point to a lack of harmony between the ongoing changes to the field; the new requirements for accountability, a competitive pressure, and new rules applied to practice in combination with a nursing habitus anchored in the traditional nursing paradigm. Standardized nursing is seen as a degradation of nursing competence, 
and the frustration of these nurses addresses what they see as a de-skilling of their work where what was formerly capital in nursing is now losing value. Indeed, they complain that caring nursing actions fall below the radar of recognized nursing practices in the department.

\section{Between curing and caring: finding one's way around the problems}

A group of nurses in the department is, however, characterized by not radically favoring a stance either for or against evidence and standardization. Convinced by the persuasive arguments of evidence, they make an effort to apply the new rules to practice whenever it makes sense to do so, and can be remembered. Memory as a theme is often discussed among the nurses, and at staff meetings. The nurses explain that they often forget the specifics of the new rules to practice, and that forgetfulness should not be confused with resistance to change. I followed Laura on a night shift. Working at the computer documenting her work in the nursing care plan she explained:

It's hard to remember what has to be inserted into each field and how things should be written. We have to use fixed terms because otherwise they can't get the statistics out. You know, these fixed terms are used as search terms in the system. I don't know what the generated information is used for, and if it used at all... Much of what we do here seems unnecessary, and it takes time away from the patients (fieldnotes).

I then asked her how she perceived the efforts to raise quality standards and patient safety in the department, and if the reporting and documentation work made sense. Her reply shows the compelling force of the arguments for standardization:

It does make sense. Standardization saves lives-that has been proven. I think patient safety is a good argument for why we must do all these things. I don't question it, and I don't argue against it. That would be a waste of efforts (fieldnotes).

While an altruistic philosophy of wanting the best for the patients seems to be the ultimate legitimizing argument for both curing and caring nursing praxis in the department, curing is enjoying a vantage point through the perception that "evidence-based" and standardized means indisputable. This is reinforced by the rhetoric on patient safety, which is repeated time and again by the department management, the hospital management, the Danish Society for Patient Safety, and curing oriented colleagues. Central for this rhetoric is the message that standardization saves lives. The statements above illustrate the power of this rhetoric through its capacity to imbue practice with meaning, and, hence, to convert itself to capital in the field.

The topic of memorizing in practice is fundamental for an understanding of why standardization is difficult, and how evidence is mobilized in practice. In a Bourdieuan lens, practice is embodied and to a large degree automatized action in a field (Bourdieu, 1990, p. 67). Altering practices or acquiring new habits in practice does not result from the adoption of a different mindset, other attitudes, etc., nor does it result from the application of theory onto practice. Being in the world and acting in it happens in the unique meeting between the possibilities and limitations of a situation and the dispositions one 
have acquired through time that makes some actions intelligible and others not (Larsen et al., 2002). As a result, "major revisions" take place slowly, and only through intelligibility, that is, when field, habitus, and practice accord and the world makes sense.

While standardization is by many recognized as generating better results regarding quality and patient safety, some nurses argue that this comes at the price of trivializing practice, which is explained as a limitation of the ability and freedom in practice to utilize ones' competences. Cathryn explains:

Standardization secures a bottom quality level by reducing variation which is good, yet it also trivializes nursing. It is well suited for inexperienced nurses due to their insecurity in many situations. The problem is that the standards are often not meaningful. This happens, for example, when the patient suffers from multiple diagnoses. Then we have to find our own ways around the problem (fieldnotes).

Standardization is meant to reduce complexity in daily practice. However, what may seem as simplifying solutions which cut down the number of alternative actions also allows for greater complexity within the actions (Timmermans \& Epstein, 2010). This is illustrated in the following excerpt wherein Beth at a meeting tells some of her colleagues about a frustrating experience she had with moving a patient from the emergency department to a bed unit:

Yesterday I was losing my nerve over a nurse from the medical ward when I phoned her to hand over a patient. His condition was quite complex, but she wouldn't allow me to pass on all the details of the case because she insisted that our conversation be conducted according to the Patient Safe standard. When I tried to tell her that there was additional information I thought she would appreciate - besides that conveyed according to the standard - she cut me off, and insisted that we kept our conversation by the book (fieldnotes).

The two latter excerpts are illustrative of the gap between what Bourdieu (1990, pp. 13, 73) terms the modus operandi and the opus operatum. The practice of handing over a patient is standardized according to the opus operatum. Standardization is delimiting action as a structured space of possibilities. However, in the modus operandi, in the real time carrying out of practice, all the impossibilities and unforeseen things happen, and the nurses must find their ways around the problems as Cathryn explains. By trying to sidestep the standard, Beth attempts at protecting the patient against errors due to misunderstandings and lack of information in the handover situation. Timmermans and Epstein (2010) argue that: "No rule can adequately capture the requisite work of prescribed action," and the excerpt exemplifies a problem many nurses pointed to that standardization of practice and a strict demand for adherence by the book actually may render practice more unsafe.

\section{Discussion and conclusion}

Applying Bourdieu's field concept, the article briefly outlined how medical evidence has achieved dominance in the healthcare field and the hospital sector, and its avenue into nursing practice where it informs the curing approach. The current dominance of 
evidence-based practice is hence a historical product that has gained a tailwind because it offers a solution to quality and efficiency-related problems in Danish healthcare. These problems were constructed as pressing by powerful and respected agents in healthcare such as the OECD and WHO. Medical evidence offers certainty in clinical decision making and has by agents in the field, such as the Danish Society for Patient Safety, been established as a necessary foundation for raising quality and patient safety in the hospital sector. In this way, it has been imbued with symbolic capacities with a strong normative element. Along these lines, curing has become an orthodoxy, explained by Bourdieu (1977, p. 169) as "a right, correct, and dominant vision established against competing visions." Curing renders practice measurable and controllable thereby lending it to the NPM agenda. The article illustrates how the problems, visions, and ideas for solutions in the healthcare field impinge on nurses and nursing work in a Danish IED. Here, the increasing standardization of practice reflects the ambitions by the hospital and departmental management of pursuing a progressive line toward the issue of quality, efficiency, and safety. This line empowers the curing nursing ethos at the expense of the caring ethos in the department.

Curing and caring can thus be understood as end points on a paradigmatic continuum informing practice (Baumann et al., 1998; Webb, 1996). Curing is oriented toward science and the illness of the patient. Caring is informed by humanistic and pluralistic epistemologies and oriented toward the patient as a person (Apesoa-Varano et al., 2011; Glouberman \& Mintzberg, 2001a, 2001b). Caring cannot be quantified and standardized because it, to a large degree, relies on the embodied abilities of the nurse to assess clinical situations. Reflecting the historically constituted battle for the legitimacy of nursing in the medical field, curing seeks to upgrade the position of nursing in relation to medicine through the accumulation of theoretical capital. Caring, on the other hand, positions nursing as everything medicine and curing is not; that which is seen as distinctive for nursing: the emotional, practical, and intuitive interest in the patient. In a Bourdieuan conception, these are battles for the creation of professional differentiation and distinction through different forms of capital.

My study points to both positive and negative effects concerning the nurses' responses to the changes of the field. The dominance of the curing approach has created new positional dynamics in the department that take shape as strategies in practice. The positional dynamics and strategizing in practice result from the match or mismatch between the new conditions of work and the nursing habitus. The career opportunities of the curing approach have created a space for the scientific-oriented and entrepreneurial nursing habitus that accords with NPM's incitement to entrepreneurial activities. To the scientifically oriented nurses, the curing ethos represents nursing progression. These nurses have been able to benefit from the status quo, and convert the imposed changes on practice to capital. The nurses adhering to the caring ethos, on the other hand, are uneasy in the field because their nursing habitus is not attuned to the new conditions of work. They experience a curtailment of professional autonomy and complain that caring nursing actions fall below the radar of recognized nursing practices in the department. Hence, the caring skills that were formerly capital in nursing are now losing value.

There is, however, a large group who seeks to juggle between curing and caring. These are nurses who, on the one hand, acknowledge and believe in central elements of the curing ethos and find themselves convinced by the association between evidence, truth, and better practice. But, on the other hand, they experience that standardization 
takes competence and enthusiasm out of practice, and that complex situations occur where the standards cannot adequately direct appropriate action, and in some situations are perceived to render practice more unsafe. The latter can be seen as illustrative of a gap between the modus operandi and the opus operatum as described by Bourdieu (1990). The fact that standardized practice is promoted as non-negotiable rules in practice creates an uneasy tension in the efforts to create intelligibility in practice. I henceforth arrive at an answer to the question I posed in the heading of this article. Medical evidence and standardization is in concord with NPM's intentions of gaining control over practice and practitioners, which reinforces a movement in the field toward the curing ethos of nursing. In the department, nursing is therefore legitimized through this ethos by being "safe," comparable, and measurable. This, however, devalues nursing practices that do not comply with these attributes.

While my studies point to a reinforced professional stratification in the department, as well as tension and dilemmas in daily work, it also illuminates other unintended effects of the NPM agenda. I thus assert that the wish for control and steering in the shape of a normative "one way" direction in practice in combination with the pressure for increased efficiency have profound consequences for the working lives of the nurses, but also for the services produced. It is, for example, illustrated how the nurses work to compensate for the inability of the standards to forecast practice and therefore to ensure good patient care. In this way, my findings are in line with the assertion made by Glouberman and Mintzberg (2001a) and Timmermans and Epstein (2010) that a detailed controlling of clinical services creates new problems. Hence, in spite of varying steering tools applied in practice, the unpredictability of practice demands alert staff thus, "work becomes professional precisely because it requires nuanced judgement" (Glouberman \& Mintzberg, 2001b, p. 5).

Hospital services are the products of people. Therefore, motivation, commitment, and quality of working life become key factors in their production. It is thus well documented in the literature that public sector productivity is closely connected to workers' quality of working-life experiences (Kamp et al., 2013, pp. 22, 52-59; Ramstad, 2014; Urban \& Wagner, 2013). This can hardly be ignored in the light of the stated enhancement goals, because it is through these practitioners that developments take place, yet, this is a neglected factor in the public sector modernization efforts where the application of control measures and rules in practice have come to dominate (Kamp et al., 2013). The question of how improvements of hospital services can best be achieved surely remains perennial. My point is not to argue against quality in care or evidencebased practice, however, based on the work presented here, I suggest that a more flexible approach to "best practice" that grants greater trust in practitioners' practical knowledge, and hence forwards a better integration of caring and curing may point to a more productive avenue in the pursuit of overall improvements.

\section{References}

Allen, D. 1997. The nursing-medical boundary: a negotiated order? Sociology of Health \& Illness, 19, 498-520 doi: http://dx.doi.org/10.1111/j.1467-9566.1997.tb00415.x.

Andersen, P. T. \& Jensen, J.-J. 2010. Healthcare reform in Denmark. Scandinavian Journal of Public Health, 38, 246-252 doi: http://dx.doi.org/10.1177/1403494809350521. 
Apesoa-Varano, E. C. 2007. Educated caring: The emergence of professional identity among nurses. Qualitative Sociology, 30, 249-274 doi: http://dx.doi.org/10.1007/s11133-0079069-6.

Apesoa-Varano, E. C., Barker, J. C. \& Hinton, L. 2011. Curing and Caring: The Work of Primary Care Physicians With Dementia Patients. Qualitative Health Research, 21, 14691483 doi: http://dx.doi.org/10.1177/1049732311412788.

Battilana, J. 2011. The enabling role of social position in diverging from the institutional status quo: evidence from the UK National Health Service. Organization Science, 22, 817-834 doi: http://dx.doi.org/10.1287/orsc.1100.0574.

Baumann, A. O., Deber, R. B., Silverman, B. E., Mallette, C. M. \& Baumann, A. 1998. Who cares? Who cures? The ongoing debate in the provision of health care. Journal of Advanced Nursing, 28, 1040-1045 doi: http://dx.doi.org/10.1046/j.1365-2648.1998.00809.x.

Baumann, S. L. 2010. The Limitations of Evidenced-Based Practice. Nursing Science Quarterly, 23, 226-230 doi: http://dx.doi.org/10.1177/0894318410371833.

Birkelund, R. 2006. Evidensideologi og forskningsstrategi: Udvikling eller afvikling? (Evidence ideology and research strategy: Development or phaseout?) Tidsskrift for Akademiske Sygeplejersker, 4-11.

Boge, J. \& Martinsen, K. 2006. Kritiske kommentarer til evidensbasert undervisning og praksis. (Critical comments to evidence-based instruction and practice) Vard $i$ Norden, 26, 32 doi: http://dx.doi.org/10.1177/010740830602600207.

Boge, J., Martinsen, K. \& Kristoffersen, K. 2009. Politikk styrer sjukepleiefaget. (Politics controls nursing) sykepleien, 15, 54 doi: http://dx.doi.org/10.4220/sykepleiens.2009.0115.

Bourdieu, P. 1977. Outline of a Theory of Practice Cambridge, Cambridge University Press.

Bourdieu, P. 1981. Men and machines. Advances in social theory and methodology, 304-317.

Bourdieu, P. 1985. The social space and the genesis of groups. Theory and society, 14, 723744 doi: http://dx.doi.org/10.1007/bf00174048.

Bourdieu, P. 1989. Social Space and Symbolic Power. Sociological Theory, 7, 14-25 doi: http:// dx.doi.org/10.2307/202060.

Bourdieu, P. 1990. The Logic of Practice, Cambridge, Polity Press.

Bourdieu, P. 1998. Practical reason: On the theory of action, Cambridge, Polity Press.

Bourdieu, P. 1999. The weight of the world: Social suffering in contemporary society, Stanford University Press.

Bourdieu, P. \& Wacquant, L. J. D. 1992. An Invitation to Reflexive Sociology, Cambridge, Polity Press.

Christiansen, T. 2012. Ten years of structural reforms in Danish healthcare. Health policy, 106, 114-119 doi: http://dx.doi.org/10.1016/j.healthpol.2012.03.019.

Coffey, A. \& Atkinson, P. 1996. Making sense of qualitative data: Complementary research strategies, Sage Publications, Inc.

Delmar, C. 2005. Er du mere katolsk end paven?-anvendelse af evidens i sygeplejen. Klinisk sygepleje, 19, 28-34.

Evetts, J. 2009. New professionalism and New Public Management: Changes, Continuities and Consequences. Comparative Sociology, 8, 247-266 doi: http://dx.doi. org/10.1163/156913309x421655.

Evetts, J. 2011. A new professionalism? Challenges and opportunities. Current Sociology, 59, 406-422 doi: http://dx.doi.org/10.1177/0011392111402585.

Exton, R. 2010. Enterprising health. Creating the conditions for entrepreneurial behaviour as a strategy for effective and sustainable change in health services. Journal of Health Organization and Management 24, 459-479 doi: http://dx.doi.org/10.1108/14777261011070493.

Fagermoen, M. S. 1997. Professional identity: values embedded in meaningful nursing practice. Journal of advanced nursing, 25, 434-441 doi: http://dx.doi.org/10.1046/j.13652648.1997.1997025434.x. 
Gibson, T. 2013. The Entrepreneurial Rationalities of Governing and the Construction of the Enterprising Nurse. Qualitative health research, 23, 93-104 doi: http://dx.doi. org/10.1177/1049732312467233.

Glouberman, S. \& Mintzberg, H. 2001a. Managing the care of health and the cure of disease--Part I: Differentiation. Health care management review, 26, 56 doi: http://dx.doi. org/10.1097/00004010-200101000-00006.

Glouberman, S. \& Mintzberg, H. 2001b. Managing the care of health and the cure of disease--Part II: Integration. Health care management review, 26, 70 doi: http://dx.doi. org/10.1097/00004010-200101000-00007.

Greve, C. 2006. Public management reform in Denmark. Public management review, 8, 161169 doi: http://dx.doi.org/10.1080/14719030500518956.

Hansen, S. R., Mathiasen, A.-K. \& Schmelling, W. 2012. Kunsten at udvikle en evidensbaseret kultur baseret på faglig ledelse (The art of developing an evidence-based culture based on professional leadership) Sygeplejersken / Danish Journal of Nursing, 8, 68-72.

Hauck, S., Winsett, R. P. \& Kuric, J. 2013. Leadership facilitation strategies to establish evidence-based practice in an acute care hospital. Journal of Advanced Nursing, 69, 664674 doi: http://dx.doi.org/10.1111/j.1365-2648.2012.06053.x.

Healy, K. 2009. A case of mistaken identity: The social welfare professions and New Public Management. Journal of Sociology, 45, 401-418 doi: http://dx.doi. org/10.1177/1440783309346476.

Holen, M. 2012. Hvad er sygepleje? (What is nursing?). Sygepleje og sygeplejerskens rolle $i$ dagens sunhedsvosen - et debatoploeg. Dansk Sygeplejeråd.

Holmes, D., Murray, S. J., Perron, A. \& Mccabe, J. 2008. Nursing Best Practice Guidelines: reflecting on the obscene rise of the void. Journal of Nursing Management, 16, 394-403 doi: http://dx.doi.org/10.1111/j.1365-2834.2008.00858.x.

Hujala, A., Andri, M. \& Kyriakidou, O. 2014. Professional autonomy under pressure: towards a dialectical approach. Journal of Health Organization and Management, 28, 635-652 doi: http://dx.doi.org/10.1108/jhom-10-2013-0224.

Høyen, M. 2005. Den faglige selvforståelse: En undersøgelse af faggruppers ethos baseret på Pierre Bourdieus sociologi (The professional self-understanding: An examination of the ethoses of professional groups grounded in Pierrre Bourdieu's sociology ). Ph.d afhandling, Den kgl. Veterinær- og Landbohøjskole.

Jenkins, E. K. 2014. The politics of knowledge: implications for understanding and addressing mental health and illness. Nursing Inquiry, 21, 3-10 doi: http://dx.doi.org/10.1111/ nin.12026.

Kamp, A., Hohnen, P., Hvid, H. \& Scheller, V. K. 2013. New Public Management-Konsekvenser for arbejdsmiljø og produktivitet. Skriftserie for Center For Arbejdslivsforskning (CAF), 1-81.

Kirkpatrick, I., Dent, M. \& Jespersen, P. K. 2011. The contested terrain of hospital management: Professional projects and healthcare reforms in Denmark. Current Sociology, 59, 489-506 doi: http://dx.doi.org/10.1177/0011392111402718.

Kjerholt, M. \& Toftdahl Sørensen, O. 2014. Implementerinsbarrierer i klinisk praksis - Hvordan kan de forstås og håndteres? (Implementation barriers in clinical practice - how to understand and handle them?). In: Hølge-Hazelton, B. (ed.) Forsknings- og udviklingskultur $i$ klinisk praksis. Region Sjælland.

Knudsen, J. L., Christensen, M. E. \& Hansen, B. 2008. Regulering af kvalitet $i$ det danske sundhedsvoesen, (The regulation of quality in the Danish healthcare system), Nyt Nordisk Forlag.

Korsbek, L., Kvistgaard, L. \& Kidholm, K. 2008. Evidence based practice strengthens nurses' professional identity [Danish]. Sygeplejersken / Danish Journal of Nursing, 108, $52-55$. 
Kottow, M. H. 2001. Between caring and curing. Nursing Philosophy, 2, 53-61 doi: http:// dx.doi.org/10.1046/j.1466-769x.2001.00031.x.

Kunda, G. 2013. Reflections on becoming an ethnographer. Journal of Organizational Ethnography, 2, 4-22 doi: http://dx.doi.org/10.1108/joe-12-2012-0061.

Kvale, S. \& Brinkmann, S. 2009. Interviews: Learning the craft of qualitative research interviewing, Sage.

Lamaison, P. \& Bourdieu, P. 1986. From Rules to Strategies: An Interview with Pierre Bourdieu. Cultural Anthropology, 1, 110-120 doi: http://dx.doi.org/10.1525/can.1986. 1.1.02a00060.

Larsen, K. 2008. Sundhedsprofessionernes kamp - hvorfor opretholdes status quo over tid?om stabiliserende faktorer i det medicinske felt (The battle of the health professions- why is status quo upheld over time? About stabilizing factors in the medical field). In: Petersen, K. A. \& Høyen, M. (eds.) At satte spor pà en vandring fra Aquinas til Bourdieu. Forlaget Hexis.

Larsen, K. (ed.) 2013. Social position i rum, krop og identitet. (Social position in space, body and identity), Oslo, Cappelen Damm Akademisk.

Larsen, K., Adamsen, L., Bjerregaard, L. \& Madsen, J. K. 2002. There is no gap 'per se' between theory and practice: Research knowledge and clinical knowledge are developed in different contexts and follow their own logic. Nursing outlook, 50, 204-212 doi: http:// dx.doi.org/10.1067/mno.2002.127724.

Latimer, J. 2014. Guest editorial: Nursing, the politics of organisation and meanings of care. Journal of Research in Nursing, 19, 537-545 doi: http://dx.doi.org/10.1177/ 1744987114562151.

Lester, J. N. \& O'reilly, M. 2015. Is Evidence-Based Practice a Threat to the Progress of the Qualitative Community? Arguments From the Bottom of the Pyramid. Qualitative Inquiry, doi: http://dx.doi.org/10.1177/1077800414563808.

Mcmurray, R. 2011. The struggle to professionalize: An ethnographic account of the occupational position of Advanced Nurse Practitioners. Human relations, 64, 801-822 doi: http://dx.doi.org/10.1177/0018726710387949.

Mulhall, A. 2002. Nursing research and nursing practice: an exploration of two different cultures. Intensive \& critical care nursing: the official journal of the British Association of Critical Care Nurses, 18, 48-55 doi: http://dx.doi.org/10.1054/ejon.2001.0129.

Nickelsen, N. C. 2009. Rethinking interventionist research: Navigating oppositional networks in a Danish hospital. Journal of Research Practice, 5, 1-18.

Nolan, P. \& Bradley, E. 2008. Evidence-based practice: implications and concerns. Journal of Nursing Management, 16, 388-393 doi: http://dx.doi.org/10.1111/j.13652834.2008.00857.x.

Pedersen, O. K. 2011. Konkurrencestaten, (The competition state), København, Hans Reitzel.

Petersen, K. A. 1998. Sygeplejevidenskab - myte eller virkelighed? (Nursing science - myth or reality?). PhD, Aarhus Universitet.

Ramstad, E. 2014. Can High-involvement Innovation Practices improve Productivity and the Quality of Working-life simultaneously? Management and Employee Views on Comparison. Nordic Journal of Working Life Studies, 4, 25-45

Robbins, D. 2000. Bourdieu \& Culture, London, SAGE.

Rock, P. 2001. Symbolic Interactionism and Ethnography In: Atkinson, P., Coffey, A., Delamont, S., Lofland, J. \& Lofland, L. (eds.) Handbook of Ethnography. SAGE Pulications Ltd.

Sackett, D. L., Rosenberg, W. M. C., Gray, J. a. M., Haynes, R. B. \& Richardson, W. S. 1996. Evidence based medicine: what it is and what it isn't. BMJ, 312, 71-72 doi: http://dx.doi. org/10.1136/bmj.312.7023.71.

Saltman, R. B., Figueras, J. \& Sakellarides, C. 1998. Critical challenges for health care reform in Europe, McGraw-Hill Education (UK). 
Schaffer, M. A., Sandau, K. E. \& Diedrick, L. 2013. Evidence-based practice models for organizational change: overview and practical applications. Journal of Advanced Nursing, 69, 1197-1209 doi: http://dx.doi.org/10.1111/j.1365-2648.2012.06122.x.

Selberg, R. 2013. Nursing in Times of Neoliberal Change: An Ethnographic Study of Nurses' Experiences of Work Intensification. Nordic Journal of Working Life Studies, 3, 9-36.

Tatli, A. 2011. A Multi-layered Exploration of the Diversity Management Field: Diversity Discourses, Practices and Practitioners in the UK. British Journal of Management, 22, 238-253 doi: http://dx.doi.org/10.1111/j.1467-8551.2010.00730.x.

Taylor, S. \& Allen, D. 2007. Visions of evidence-based nursing practice. Nurse researcher, 15, 78-83 doi: http://dx.doi.org/10.7748/nr2007.10.15.1.78.c6057.

Timmermans, S. \& Epstein, S. 2010. A World of Standards but not a Standard World: Toward a Sociology of Standards and Standardization. Annual Review of Sociology, 36, 69-89 doi: http://dx.doi.org/10.1146/annurev.soc.012809.102629.

Timmermans, S. \& Kolker, E. S. 2004. Evidence-Based Medicine and the Reconfiguration of Medical Knowledge. Journal of Health and Social Behavior, 45, 177-193 doi: http:// dx.doi.org/10.2307/3653831.

Travaglia, J. F. \& Braithwaite, J. 2009. Analysing the "field" of patient safety employing Bourdieusian technologies. Journal of Health Organization and Management, 23:6, 597609 doi: http://dx.doi.org/10.1108/14777260911001626.

Triantafillou, P. 2007. Benchmarking in the public sector: A critical conceptual framework. Public Administration, 85, 829-846 doi: http://dx.doi.org/10.1111/j.14679299.2007.00669.x.

Triantafillou, P. 2014. Against all odds? Understanding the emergence of accreditation of the Danish hospitals. Social Science \& Medicine, 101, 78-85 doi: http://dx.doi.org/10.1111/ j.1467-9299.2007.00669.x.

Urban, A.-M. \& Wagner, J. I. 2013. Another link to improving the working environment in acute care hospitals: registered nurses' spirit at work. Nursing leadership (Toronto, Ont.), 26, 77 doi: http://dx.doi.org/10.12927/cjnl.2013.23628.

Wacquant, L. 2015. For a Sociology of Flesh and Blood. Qualitative Sociology 38, 1-11 doi: http://dx.doi.org/10.1007/s11133-014-9291-y.

Webb, C. 1996. Caring, curing, coping: towards an integrated model. Journal of advanced nursing, 23, 960-968 doi: http://dx.doi.org/10.1046/j.1365-2648.1996.09715.x.

Witz, A. 2003. Professions and patriarchy, Routledge.

Yanow, D. 2012. Organizational ethnography between toolbox and world-making. Journal of Organizational Ethnography, 1, 31-42 doi: http://dx.doi.org/10.1108/20246674121 1220633.

\section{End notes}

${ }^{1}$ Integrated Emergency Department is the translation chosen by the author for the Danish Fælles Akut Modtagelse.

2 Bourdieu's use of "strategy" should not be confounded with the strategy concept of utilitarian theory (Lamaison \& Bourdieu, 1986). Rather, strategies are acts directed toward and end, yet without being recognized as such by the agents (Petersen, 1998).

${ }^{3}$ Bourdieu's use of the metaphor of a "game" does not imply agents' obedience to rules or norms. Rather the game results from the acceptance of taken for granted regularities in the field (Lamaison \& Bourdieu, 1986).

${ }^{4}$ Christiansen (2012) and Andersen and Jensen (2010) offer a detailed examination of the 2007 reform, its background, and effects. 
5 See, for example, Høyen (2005, p. 81) who analyzes the professional ethos with Bourdieu's theory.

${ }^{6}$ The Danish nursing organization members $87 \%$ of Danish nurses (in March 2015). The journal "Sygeplejersken" is distributed 14 times a year http://www.dsr.dk/Artikler/Sider/ Welcome.aspx accessed April 2015.

7 The society describes itself as an independent organization funded by the regions, grants from funds and membership fees http://www.patientsikkerhed.dk/om-os.aspx. It cooperates with partners abroad and engages in several projects and programs to enhance patient safety, among them "patient safe hospital" http://www.patientsikkerhed.dk/projekter-ogredskaber/projekter.aspx that specify "Best Practice" within 12 clinical focus areas. http:// www.patientsikkertsygehus.dk/pakker.aspx accessed April 2015.

8 The six parameters are the measurement of the patient's blood pressure, temperature, pulse, consciousness, blood saturation, and respiration rate.

${ }^{9}$ All excerpts in this section have been translated from Danish into English by the author. 